\title{
Welding Shape Memory Alloys with NdYAG lasers
}

\section{(Soldadura de ligas de memória de forma com laser Nd-YAG)}

\author{
Luisa Quintino ${ }^{1}$, Rosa M. Miranda ${ }^{2}$ \\ ${ }^{1}$ IST-UTL Instituto Superior Técnico, Universidade Técnica de Lisboa, Portugal, lquintino@ist.utl.pt \\ ${ }^{2}$ UNIDEMI, Depto. de Engenharia Mecânica e Industrial, Faculdade Ciências e Tecnologia, Universidade Nova de Lisboa, Portugal
}

\begin{abstract}
The demand of emerging joining techniques for shape memory alloys (SMA) has become of great importance, as their functional properties namely shape memory effect (SME) and superelasticity (SE) present unique solutions for state-of-the-art applications. Welding of SMAs is a challenge due to the risk of reduced mechanical performance after laser processing. The wider application of these alloys in various sectors as aerospace, medical or electronic industry is hindered by the limitations in its processing. The need to weld SMAs to other materials is pressing for applications in the above referred sectors. In dissimilar joints the need to understand materials behavior is even more challenging since base materials have different physical properties leading to different heat flow, convection processes and residual stress distribution. The chemical composition across the weld pool varies and intermetallic compounds are formed. Research detailing the effects of laser processing on NiTi is essential to overcome many of these challenges. The objectives of the current study are to analyze the effects of laser welding in the weld shape of both similar and dissimilar joints of NiTi to stainless steel and titanium alloys.
\end{abstract}

Key-words: NiTi, Stainless steel, Ti alloys, Laser welding.

Resumo: A procura de técnicas de ligação para ligas de memória de forma tem-se revetido de importância crescente, devido ao desenvolvimento de aplicações deste material com particulares propriedades de memória de forma e superelasticidade. A soldadura de ligas de memória de forma é um desafio devido ao risco de emporbrecimento das propriedades mecânicas depois do processamento laser. A aplicação alargarda destas ligas em vários sectores como o aeroespacial, medico ou electrónico é prejudicado pelas limitações de processamento. A necessidade de soldar ligas de memória de forma a outros materiais é premente para estes sectores. Em juntas dissimilares, o entendimento do comportamento dos materaias é um desafio ainda maior uma vez que os materias base têm propriedades diferentes com consquentes diferenças no escoamento térmico, movimentação de fuido e distribuição de tensões residuais. A composição química varia ao longo do banho de fusão e formam-se compostos intermetálicos. É essencial realizar-se investigação sobre estes efeitos do processamento laser de NiTi para ultrapassar este desafio. O presente estudo visa analisar os efeitos da soldadura a laser na forma do cordão de soldadura em juntas similares e dissimilares de NiTi com aço inoxidável e ligas de titâneo.

Palavras-chave: NiTi, Aço inoxidável, Ligas de Ti, Soldadura a laser.

\section{Introduction}

Shape memory alloys were first produced in the 1950's. By that time the martensitic transformation, as a reversible thermoelastic process, different from the one found in the $\mathrm{Fe}-\mathrm{C}$ system had already been introduced by Kurdjumov and Khandros in 1949, which reported the "thermoelastic behavior of the martensitic phase of Au-Cd alloys".

Otsuka and Wayman [1] reported that the functional properties of SMA were first discovered in 1951 in 74.5 at. \% Au-Cd alloy. With the discovery of Nitinol (a NiTi SMA) by Buehler and his co-workers at the Naval Ordnance Laboratory [2], SMAs captured definitely the interest of the scientific world,

(Convidado em 15/05/2012; Texto final em 03/09/2012). in the early sixties.

The continuous growth of these alloys led to the development of particular applications, by controlling its functionalities (e.g. transformation temperatures) via composition, manufacturing technology, thermal and thermomechanical treatments.

One of the first applications of SMAs has been in orthodontics in 1972 by Andreasen et al [3], who suggested for the first time the use of superelastic Nitinol wire. In the 70's, when a new SMA named "high temperature SMA" was developed by alloying Ti with $\mathrm{Pd}, \mathrm{Pt}$ and $\mathrm{Au}$, increasing transformation temperatures (above $100^{\circ} \mathrm{C}$ ) further applications were possible. Nevertheless it was in the 80's that SMAs found many other applications for medical purposes on orthopedics, radiology and guidewires technology [4]. In late 90's the effect of numerous elements on NiTi has been studied in order to improve the properties (higher or lower transformation temperatures, transformation hysteresis, mechanical and thermomechanical properties, etc.). For example, NiTiCu alloys were found to improve fatigue life, 
making them very much attractive for cyclic applications [5]. Nowadays, new challenges come from aerospace and micro engineering, for applications involving high temperature and hostile environments.

The poor workability of SMAs by conventional machining processes and their increasing application demands suitable joining techniques in order to obtain complex components $[6$, 7]. In the last two decades the number of experiments reported in the literature concerning welding joining techniques of shape memory alloys has increased significantly [8].

Traditional welding processes were mainly tested, but the increasing requirements to perform specific tasks lead to the employment of state of the art technologies, like laser welding, with promising results. Welding SMAs is a challenge when compared to conventional welding techniques performed on steels or other well known alloys. Unlike those materials, mechanical properties and corrosion resistance are strongly dependent on chemical composition, microstructure and transformation temperatures.

Dissimilar metal welds are in many aspects different from similar ones. Base material thermo-physical properties are usually different, leading to different heat transfer rates on both sides of the weld. During the process, composition varies across the weld pool, and it is not clear the interface between solid-liquid phases. Intermetallic compounds are formed and convection processes occur, like Marangoni effects, since base metal densities vary significantly.

First studies on dissimilar weld of $\mathrm{Ti}$ and $\mathrm{Ni}$ concluded that results are strongly limited by the formation of brittle intermetallics that lead to cracking. Detailed studies on the solidification mechanism were conducted $[9,10]$ reporting the microstructural evolution in the fusion zone of a dissimilar NiTi weld. Embrittlement occurs mainly due to high temperatures reaction of elements such as oxygen, nitrogen and hydrogen. Brittle intermetallics like Ti2Ni and TiNi3 can also form during solidification with adverse effects on strength and shape memory effect. In order to fulfill specific needs of medical industry, welding experiments on dissimilar joints like NiTi/stainless steel or Hastealloys were performed. In the aerospace industry new parts like gas turbine nozzles are being tested using NiTi and Ti-6Al-4V, previously joined by fasteners [11].

The similar and dissimilar welding of NiTi with lasers has been reported to have potential for obtaining joint properties adequate to a large range of applications, but in order to assure the required quality a comprehensive understanding of the effect of the laser beam on the materials properties, is needed. The present paper outlines the results obtained in joints laser welded in similar NiTi and dissimilar NiTi/Ti and NiTi/Stainless steel, by observation of weld macrographs.

\section{Laser Welding}

The basic principle of laser welding is that a laser beam radiation produced in a resonator cavity is focused on the material surface through an optical system. The effectiveness of the beam coupling depends on the wavelength of the beam radiation and the optical properties of the material including the surface condition.

Amongst the operating factors influencing the shape and properties of the molten pool and, thus the weld, absolute and relative factors can be identified. The absolute factors are related to:

- laser beam: wavelength, power, power distribution, operating mode, spot size

- materials: chemical composition, thermo-physical properties, microstructure, geometry and dimensions

- shielding gas: composition, flow rate, flow configuration

- filler material: chemical composition, thermo-physical properties, type and dimensions.

The relative factors are:

- relative position of laser beam, welding materials, shielding gas and filler material

- welding speed, filler material and feeding rate.

The high energy density allows confining the weld metal to a very localized narrow zone with low heat being conducted away from this molten pool, leading to a narrow heat affected zone. The process is very precise, clean, and the resulting phase transformations minimized due to the rapid weld thermal cycle.

Laser welding has been extensively studied by several R\&D groups due to its particular characteristics [12,13]. Both $\mathrm{CO} 2$ and $\mathrm{Nd}$ :YAG lasers have been searched to join NiTi, and the effect of weld thermal cycle on shape memory properties, superelastic and mechanical behavior [13], as well as, on corrosion [14]. Although both lasers can weld NiTi, more significant effects on mechanical resistance and functional properties are observed in $\mathrm{CO} 2$ welded joints, while Nd:YAG laser welded joints keep good tensile strength and functional properties [15-18].

The present work focus on the use of Nd:YAG lasers for welding SMAs in similar and dissimilar joints, since as mentioned above, its characteristics present a higher potential for achieving good results in these materials.

\section{Similar NiTi laser joints}

\subsection{Experimental procedure}

NiTi cold rolled plates with 50.8 at.\% Ni, with $1 \mathrm{~mm}$ and $0.34 \mathrm{~mm}$ thick were used. These are commercial superelastic SMAs with Af above $0{ }^{\circ} \mathrm{C}$.. Surfaces to join were inspected and hand finished in order ensuring best surface contact along all the joint length. Surface oxides were removed by chemical etching in a HF:HNO3:H2O solution with a dilution of 1:5:10.

$\mathrm{Nd}$ :YAG laser power sources operating in continuous and pulsed wave mode, were used with a gas protection of argon injected in the face and in the weld root in a special chamber built in situ at a flow rate of $45 \mathrm{l} / \mathrm{min}$. The beam was focused to $0.4 \mathrm{~mm}$ and the focal point position (FPP) was set on the upper surface. Butt welding was performed in $1 \mathrm{~mm}$ thick plates with 
zero gap between opposite plates, on specimens aligned along and across the rolling direction. Lap joints were produced with pulsed wave laser on $0.34 \mathrm{~mm}$ thick sheets.

\subsection{Results}

A macrograph of a laser butt welded specimen with $1 \mathrm{~mm}$ thickness is depicted in Fig. 1, in which it is possible to identify the different regions in the weld and in Fig 2 the macrograph of the $0.34 \mathrm{~mm}$ foil is presented.

Similar welds of NiTi foils showed no major weldability problems, the main concern being the gas protection to avoid oxidation and porosity. A fine-grain homogeneous microstructure is observed with intermetallic precipitates of Ti2Ni concentrated at the boundary between the weld and the parent foil.

In terms of mechanical behaviour specially under cycling conditions, it was observed that the rolling direction plays an important role, as far as joint functionality is concerned, as specimens welded across the rolling direction exhibited

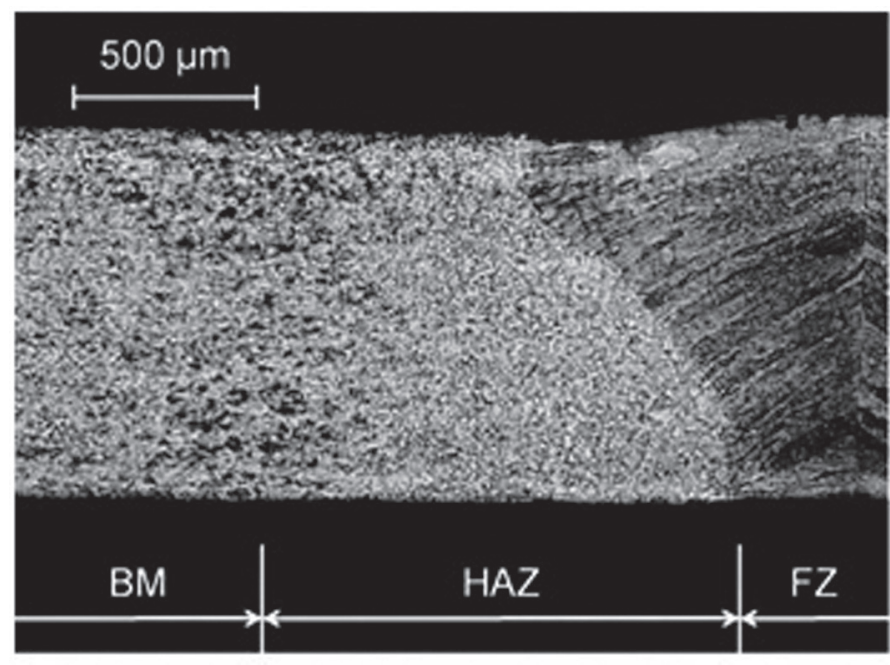

Figure 1. Macrograph of a specimen welded across the rolling direction showing the welded zones (Power: $910 \mathrm{~W}$, welding speed: $25 \mathrm{~mm} / \mathrm{s}$ )
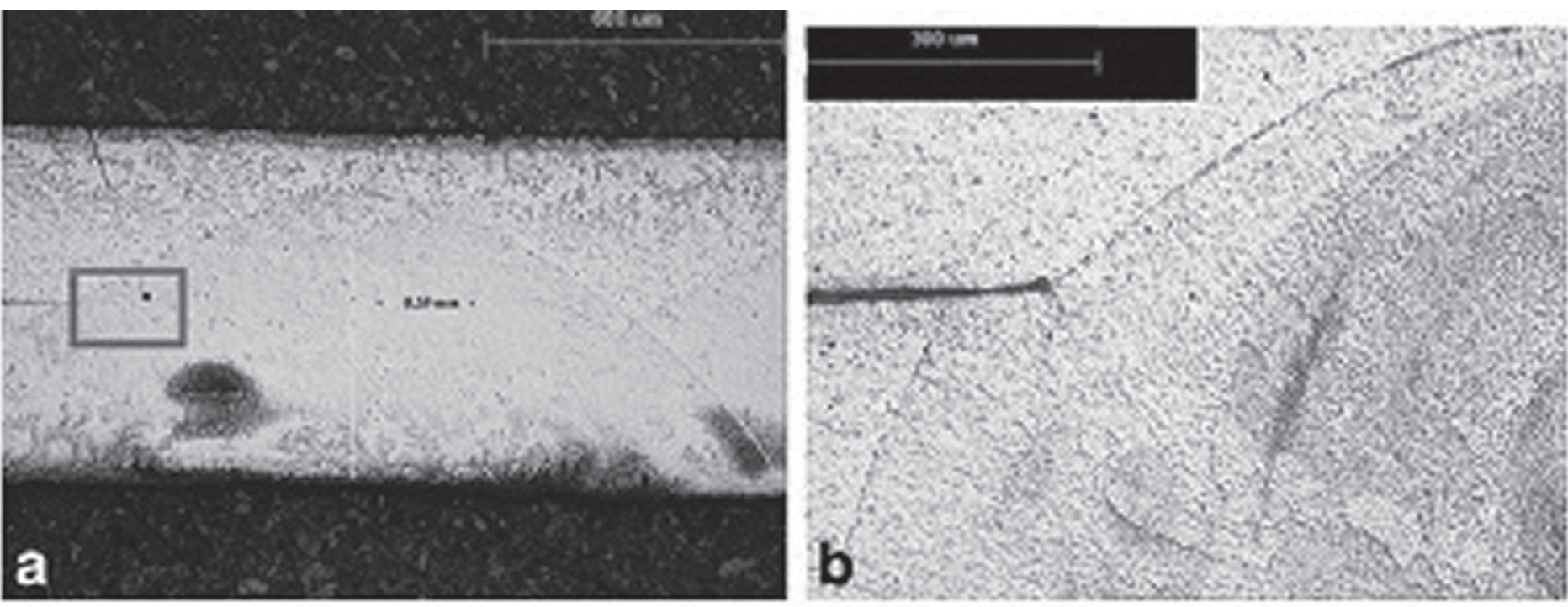

Figure 2. NiTi/NiTi weld of 0.34-mm-thick plates. a) Macrograph / b) weld microstructure.

Beam spot diameter $=1 \mathrm{~mm}$, pulse duration $=7 \mathrm{~ms}$, energy $=9.2 \mathrm{~J}$, power density $=41830 \mathrm{Wcm}^{-2}$

approximately $2.5 \%$ longer superelastic plateaus and higher UTS. This is relevant for joint design purposes.

The superelastic behaviour of the welds was observed for applied stresses close to about $50 \mathrm{MPa}$ below the ultimate tensile strength of the welded joints. The functionality of these welds for practical purposes was confirmed by means of analyzing the stabilization of the mechanical hysteretic response, to strain levels up to $8 \%$. For tensile cycling involving strain levels larger than $6 \%$, welded specimens were found to exhibit superior functional mechanical behaviour by presenting larger recoverable strain levels as shown in Fig. 3.

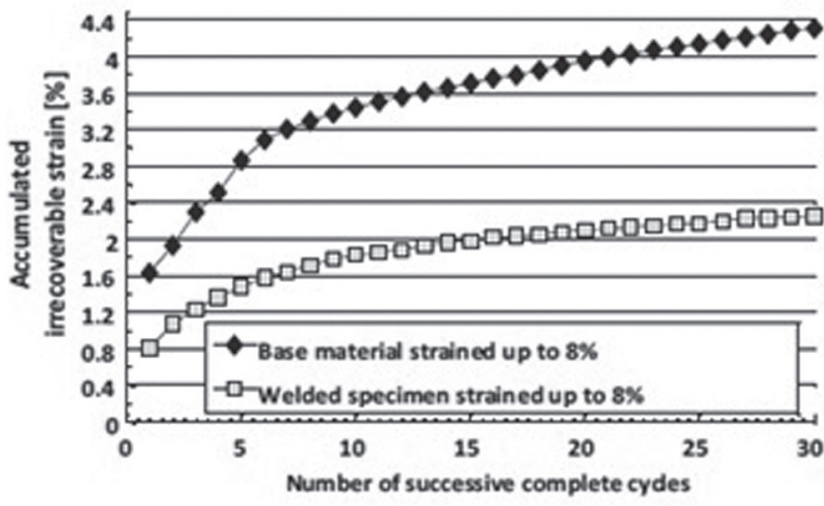

Figure 3. Comparative accumulation of inelastic strain to welded joints and base material strained up to $8 \% .13$ ] 


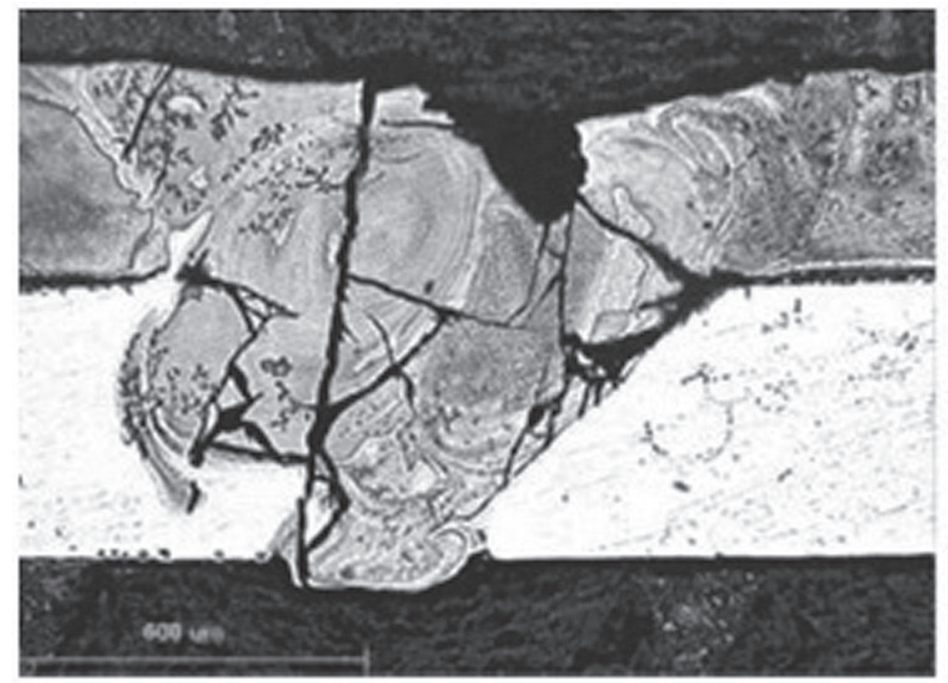

a)

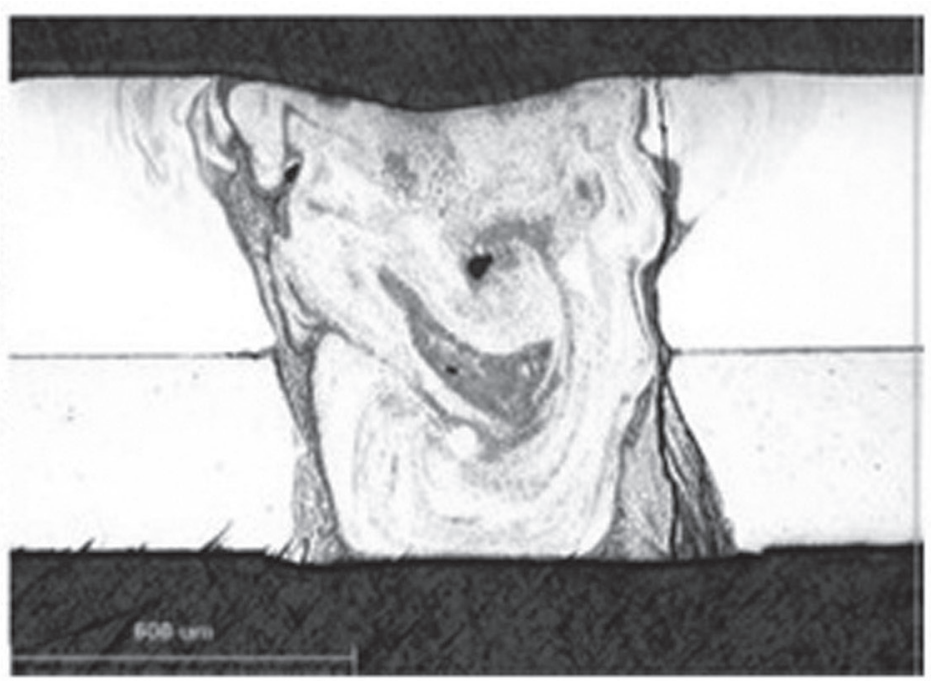

b)

Figure 4. Macrograph of a stainless steel/NiTi weld. Flash lamp, $250 \mathrm{~V}$; beam spot diameter, $1 \mathrm{~mm}$.

a) Pulse duration, $10 \mathrm{~ms}$; energy, $12.6 \mathrm{~J}$; power density, $40 \mathrm{~kW} \mathrm{~cm}^{-2}$

b) Pulse duration, $50 \mathrm{~ms}$; energy, $30.3 \mathrm{~J}$; power density, $77 \mathrm{~kW} \mathrm{~cm}{ }^{-2}$
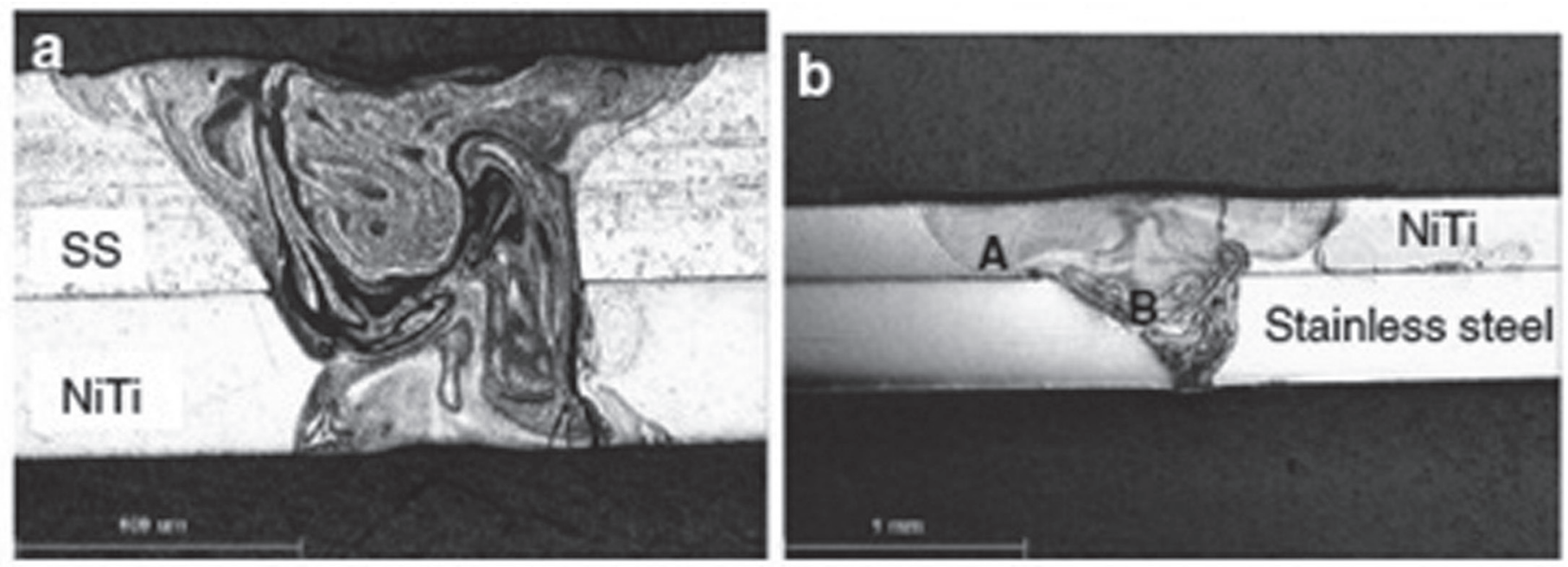

Figure 5. Macrographs of dissimilar welds. a) stainless steel/NiTi weld; b) NiTi/stainless steel

\section{Dissimilar welds between NiTi to stainless steel}

\subsection{Experimental procedure}

Commercially available NiTi foils of $0.34 \mathrm{~mm}$ thick and AISI316L of $0.47 \mathrm{~mm}$ thick were used in this study. Specimens were cut from parent plates to dimensions of $2.5 \times 0.75 \mathrm{~mm}$ and immersed in a dilute solution of hydrofluoric and nitric acids to remove black oxide prior to welding. Stainless steel samples were cleaned by washing with isopropanol to remove grease from the surface.

Laser welds were produced with a pulsed Nd:YAG LaserSWMP 6,002 from Carl Basel Lasertechnik.

Lap welds were performed with the laser beam impinging directly on the NiTi foil positioned on top of the stainless steel and inversely, with the laser beam directed to the stainless steel foil with NiTi beneath. Interlayers of nickel were also tested, with thicknesses of 0.025 and $0.125 \mathrm{~mm}$ interposed between the NiTi and the steel foils.

\subsection{Results}

When performing dissimilar lap joints, extensive cracking was observed as shown in Fig. 4a. However, by increasing the interaction time, a more uniform weld pool is observed (Fig. 4b).

The effect of material sequence was investigated. Figure 5 shows the weld pool shape when positioning NiTi above stainless steel or below, keeping the same operating conditions. It is seen that though the parameters were kept constant, the bead shapes are remarkably different. Since NiTi has a lower melting temperature $\left(1240-1310^{\circ} \mathrm{C}\right)$ compared to stainless steel $\left(1300-1400^{\circ} \mathrm{C}\right)$, it melts before the steel $[1,5]$. Additionally, the 
diffusivity of NiTi is about half of that of stainless steel (5 and 9 $\mathrm{m} 2 / \mathrm{s}$ ), respectively, so heat is dissipated in the NiTi foil slower than in the stainless steel and the weld bead is wider [19].

The global composition of the weld metal of a dissimilar weld was analysed, and results are presented in Table 1, showing the coexistence of $\mathrm{Cr}$ and $\mathrm{Ti}$.

Table 1. COMPOSITION OF THE WELD METAL (AT. \%)

\begin{tabular}{lllllll}
\hline $\mathrm{Ti}$ & $\mathrm{Ni}$ & $\mathrm{Fe}$ & $\mathrm{Cr}$ & $\mathrm{Mn}$ & $\mathrm{Si}$ & $\mathrm{O}$ \\
\hline 18.2 & 20.79 & 24.8 & 7.16 & 0.65 & 1.38 & 18.33 \\
\hline
\end{tabular}

Dissimilar welds with interlayers were performed to prevent cracking. In order to better understand the role nickel plays in the weld quality, a method of providing different amounts of nickel to the weld pool has been investigated. In a first attempt, nickel content of the weld pool varied by adding nickel interlayers between the NiTi and the stainless steel foils (Fig. 6).

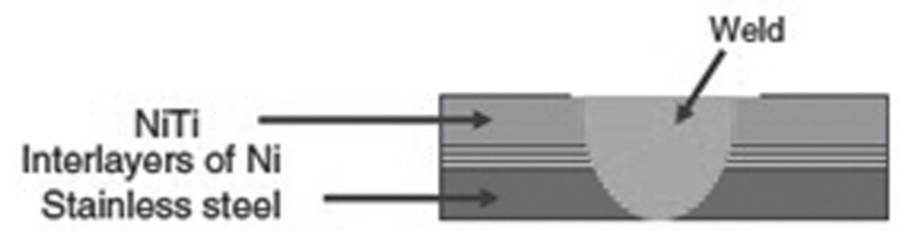

Figure 6. Expected weld shape

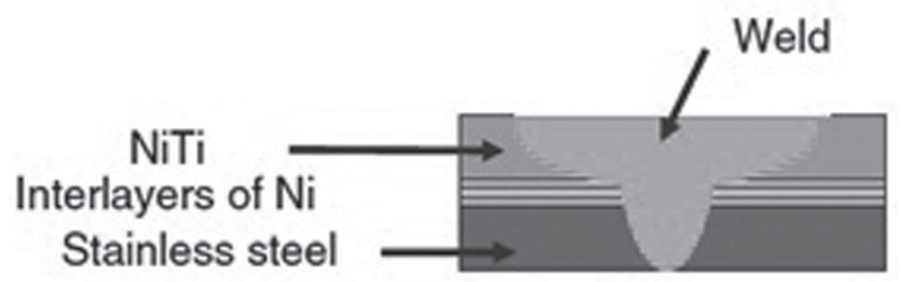

Figure 7. Obtained weld shape

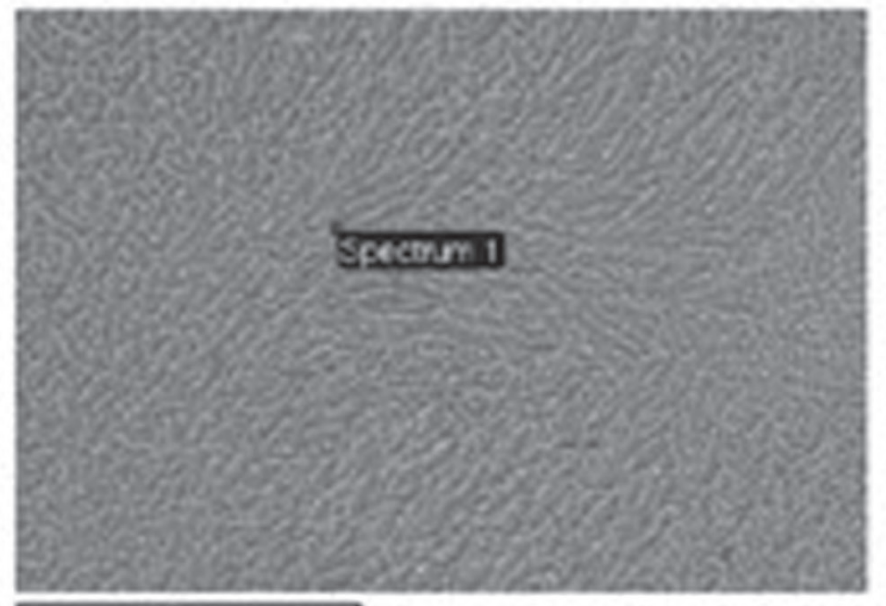

$40 \mu \mathrm{m}$
However, this method was not as efficient as expected because the weld shape obtained (Fig. 7) was larger at the top face due to the low thermal conductivity of NiTi and thus modified the volume fraction of each material and consequently the weld pool composition.

Figure 8 shows a macrograph of a weld produced with interlayers of nickel, and the absence of cracking in the weld metal is observed.

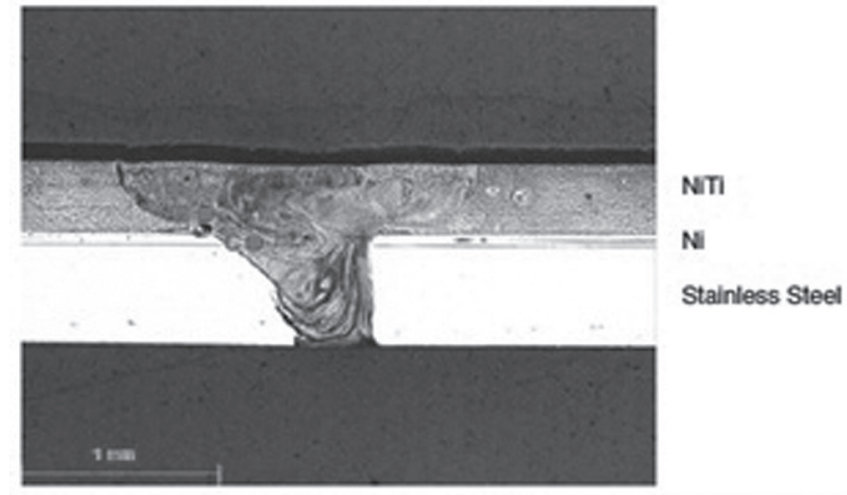

Figure 8 . NiTi/Ni $(0.05 \mathrm{~mm}) /$ stainless steel. Beam spot diameter: $1 \mathrm{~mm}$; flashlamp voltage, $260 \mathrm{~V}$; pulse energy, 30.28 $\mathrm{J}$; pulse duration, $50 \mathrm{~ms}$; intensity, $77.102 \mathrm{~W} / \mathrm{cm}^{2}$

Figure 9 shows the microstructure of the weld bead on the NiTi foil. A fine cellular dendritic structure is observed rich in $\mathrm{Ti}$ and $\mathrm{Ni}$.

Looking at the weld interface close to the nickel interlayer (Fig. 10), it is seen that Ni decreases when moving away from the layer, while the other elements increase.

The fusion zone close to the stainless steel side had a dendritic structure rich in iron and chromium but without cracking or porosity. The weld pool uniformity was found to be better with increasing pulse duration for the same penetration. Pouquet et al. [19] showed a similar effect and observed that by increasing the laser power and reducing the laser frequency, the mechanical strength of the joint increased. So, for thin NiTi foils, the pulse

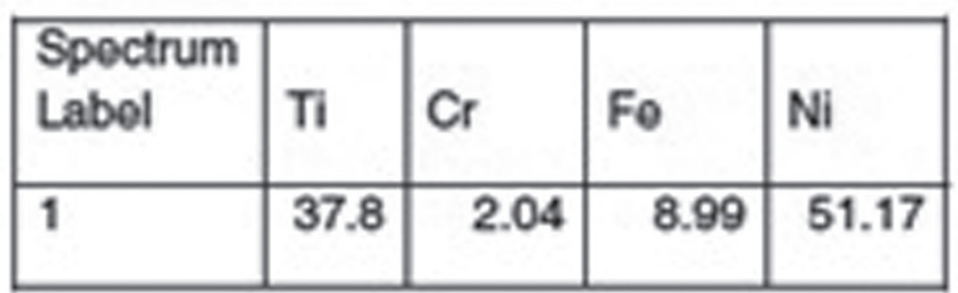

Figure 9. Microstructure and chemical composition of the weld metal 

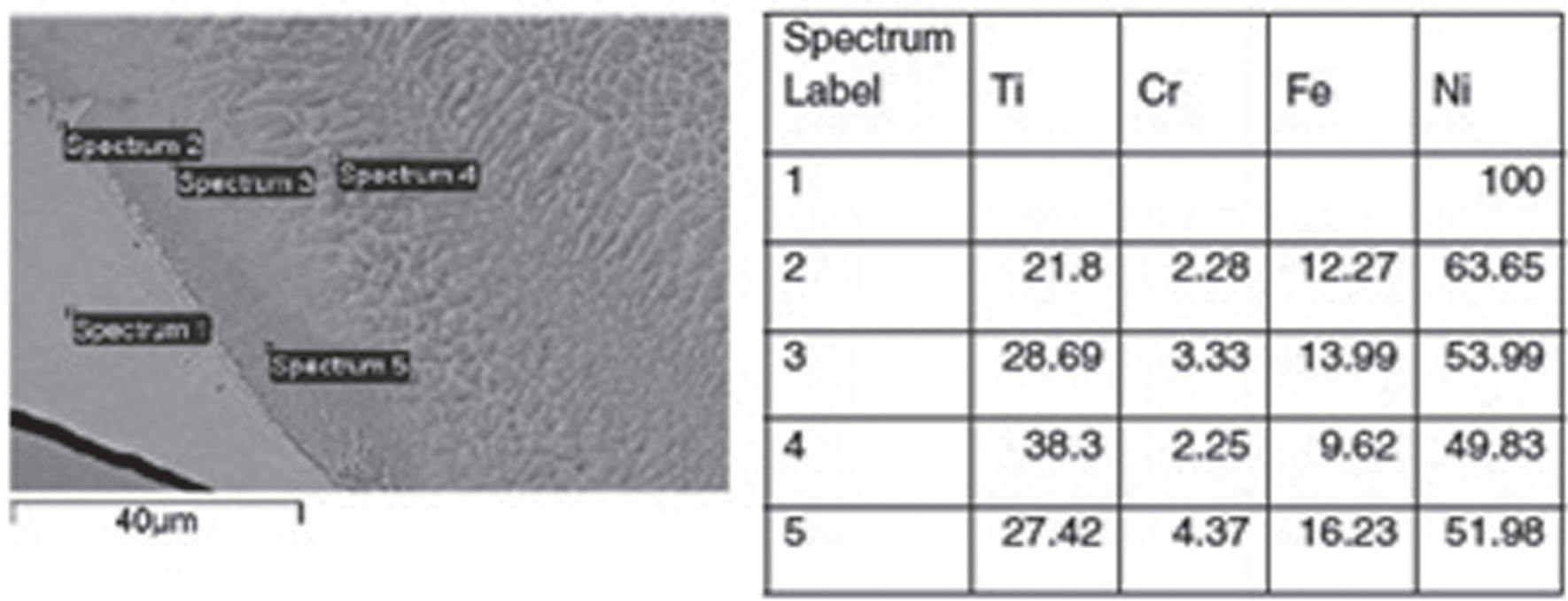

Figure 10. Microstrutcture of the fusion zone close to the Ni interlayer

energy threshold and pulse duration must be known in order to predict the intensity needed for a specific penetration.

\section{Dissimilar welds between NiTi and Ti6Al4V}

\subsection{Experimental procedure}

Several sets of experiments were conducted in dissimilar joints NiTi to Ti6Al4V alloy $1 \mathrm{~mm}$ thick using Nd:YAG laser. The procedure adopted was very much similar to the one described for similar welding in terms of gas protection and samples cleaning. Butt welds were performed at constant speed with different welding powers. Different gaps between samples were tested due to the different thermal expansion coefficients of both materials.

Preliminary tests with different powers, pulse configurations and speeds were done with severe cracking observed in most of the cases. From these preliminary testes a welding procedure with potential to achieve good results was derived: $\mathrm{P}=1.6 \mathrm{KW}$, $\mathrm{Tp}=3 \mathrm{~ms}, \mathrm{~F}=10 \mathrm{~Hz}$, spot diameter $=0.6 \mathrm{~mm}, \mathrm{v}=48 \mathrm{~mm} / \mathrm{min}$ ). This was used to produce test samples for analysis.

Another set of tests was run where the beam was focused on the Ti plate $0.2 \mathrm{~mm}$ away from the NiTi/Ti interface. The results were better than the previous. In both these testes the gap between the plates was $1 \mathrm{~mm}$. Each test was repeated to verify the reliability of the results.

\subsection{Results}

The results show that the range of parameters to obtain a good weld is very narrow and there is a balance of heat versus cooling time that still needs to be found.

In the first set of tests extensive cracking was observed in the Ti side fusion line as shown in Fig. 11 with a very fine dendritic structure with Ti2Ni identified [20,21]. This was due to constitutional phenomena specially the formation of intermetallics originated by the migration of $\mathrm{Ni}$ and its affinity with Ti.
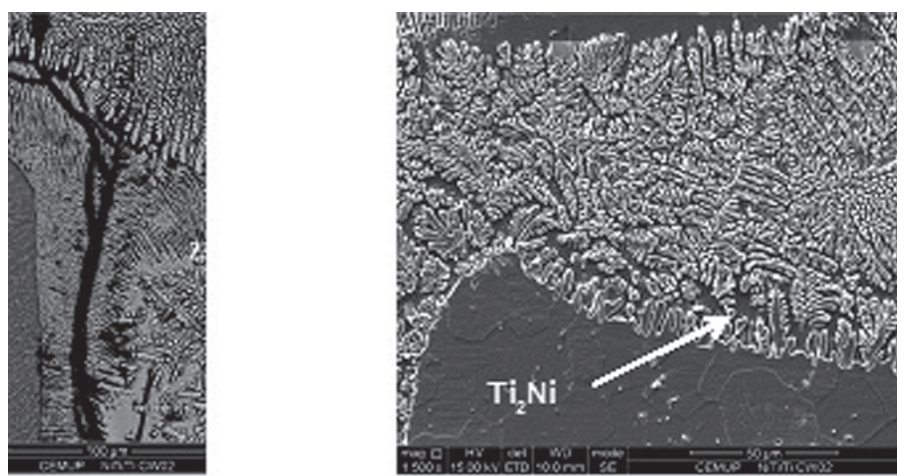

Figure 11. Details of a NiTi/Ti6A14V weld

Under CW conditions a smooth boundary between the NiTi and the Ti alloy is observed (Fig. 12). A more detailed investigation of the interface shows a band structure on the Ti6Al4V side along the whole weld of 60-70 $\mu \mathrm{m}$ [22] which is under study.

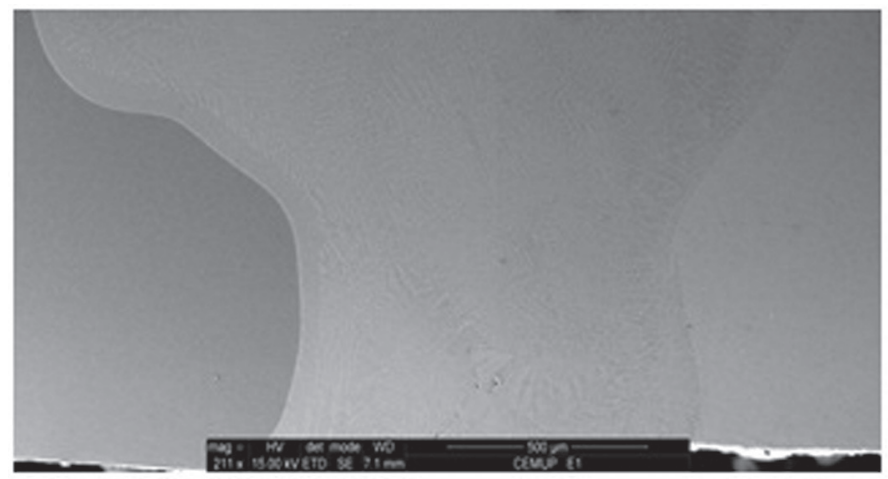

Figure 12. Macrograph of a NiTi/Ti6Al4V weld free of defects 


\section{Conclusions}

From the work performed on laser welding of NiTi the following can be concluded:

1. In similar joints

- laser welding of NiTi in similar joints can be achieved provided appropriate welding procedures are adopted.

- these joints show characteristics typical of a fusion welding process with solution annealing of the fusion zone and recrystallisation and grain growth in the HAZ.

2. In dissimilar joints the results show that particular care needs to be taken in the definition of the welding procedure since the tolerance box for achieving joining is limited.

\subsection{Dissimilar joints NiTi to stainless steel}

In order to achieve good quality dissimilar welds of NiTi to stainless steel, from the present study, the following needs to be taken in consideration:

- when welding such thin foils, fixing is fundamental to enable good contact between the parts. Fixing device acts as a heat sink.

- there is a pulse energy threshold below which welding is not obtained. The longer the pulse duration, the better is the mixing inside the weld pool.

- the weld pool composition was found to determine the brittleness of the weld. $\mathrm{Ni}$ additions suppress the formation of the brittle intermetallic Fe2Ti as the primary solidification occurs from the $\gamma(\mathrm{FeNi})$ and the Ni3Ti phases. Weld metal with more than $40 \% \mathrm{Ni}$ or $\mathrm{Fe}$ and less than $45 \% \mathrm{Ti}$ is less prone to cracking.

- the weld shape depends on the joint configuration (sequence of layers when applicable), laser welding parameters and thermal properties of the materials involved.

\subsection{Dissimilar joints NiTi to Ti6Al4V}

From research conducted on dissimilar laser welding of NiTi to Ti alloys, the following needs to be taken in consideration:

- a good control of the cooling rate has to be assured in order to avoid intermetallics formation, specially $\mathrm{Ni} 3 \mathrm{Ti}$ and $\mathrm{Ti} 2 \mathrm{Ni}$ phases.

- the formation of brittle intermetallic compounds in Ti6Al4V side are due to migration of $\mathrm{Ni}$ to (Ti) $\beta$.

- perfect bonding was obtained in some areas with sound welds free of cracks

\section{Acknowledgements}

The authors would like to acknowledge the funding of FCT/ MCTES for the project 'Joining micro to small scale systems in shape memory alloys using last generation infrared lasers' (PTDC/EME-TME/100990/2008) and the project team.

\section{References}

[1] Otsuka, K.; Wayman, C.M.; Shape Memory Materials; Cambridge University Press, Cambridge 1998.

[2] Buehler, W.J.; Gilfrich, J.V; Wiley, R.C.; Effect of LowTemperature Phase Changes on the Mechanical Properties of Alloys near Composition TiNi, Journal of Applied Physics, Vol.34 (1963) pp. 1475-1477.

[3] Andreasen, George F.; Brady, Patrick R.; A Use Hypothesis for 55 Nitinol Wire for Orthodontics, The Angle Orthodontist, Vol. 42 (1972), No.2, pp. 172-177.

[4] Pelton, A.R.; Stockel, D.; Duerig, T.W.; Medical Uses of Nitinol, Materials Science Forum Vols. 327-328 (2000) pp. 63-70, Proceedings of the International Symposium on Shape Memory Materials held Kanazawa, Japan, May 1999.

[5] Lagoudas, Dimitris C.; Shape Memory Alloys: Modeling and Engineering Applications; Springer, USA 2008.

[6] Chatterjee, S.; Abinandanan T.A.; Chattopadhyay K.; Phase formation in $\mathrm{Ti} / \mathrm{Ni}$ dissimilar welds, Materials Science and Engineering A 490 (2008) pp. 7-15.

[7] Chau, E.T.F.; Friend, C.M.; Allen, D.M.; Hora, J.; Webster, J.R.; A technical and economic appraisal of shape memory alloys for aerospace applications, Materials Science and Engineering A 438-440 (2006) pp. 589-592.

[8] Miranda, R. M.; Fernandes, F. M. Braz; Craciunescu, C. M.; Quintino, L.; Vieira, L. Alberty; Shape Memory Alloys: existing and emerging applications, Advances in Materials Science Research, vol. 6 (2011) pp. 1-23.

[9] Nishikawa, M.; Tanaka, H.; Kohda, M.; Nagaura, T.; Watanabe, K.; Behaviour of welded part of Ti-Ni shape memory alloy, J. PHYS, Colloque C4, supplement $\mathrm{n}^{\mathrm{o}} 12$, Tome 43, December 1982, pp. 839-844.

[10] Qiao, Zhixia; Li, Lianjin, Wang, Dongat; Li, Zongmin; Microstructure and shape memory recovery of a $\mathrm{Fe}-\mathrm{Mn}-\mathrm{Si}$ $\mathrm{Cr}$-Ni SMA, International Conference on Smart Materials and Nanotechnology in Engineering, China 2007.

[11] Budau, Victor; Oanca, Octavian; Craciunesau, Corneliu M.; Macro and Microscopic Aspects observed on ultrasonic welding of shape memory alloys, ed. Oradea University, Fascicle of Management and Technological Engineering, Volume VII (XVII), 2008.

[12] Eijk, Casper van der; Fostervoll, Hans; Sallom, Zuhair K.; Akselsen, Odd M.; Plasma welding of NiTi to NiTi, Stainless Steel and Hastealloy C276, ASM Materials Solutions 2003 Conference, Pittsburgh, Pennsylvania, USA, 13-15 October 2003.

[13] Miranda, R. M.; Fernandes, F. M. Braz; Silva, R. J. C.; Quintino, L.; Vieira, L. Alberty; Cuesta, A.; Ocaña, J. L.; Mechanical behaviour of Nd:YAG laser welded superelastic $\mathrm{NiTi}$, Materials Science and Engineering A, Volume 528, Nº 16-17 June 2011.

[14] Hsu, Y.T.; Wang, Y.R., Wu, S.K., Chen, C.; Effect of Laser Weld on the Shape-Memory and Corrosion Characteristics of TiNi alloys, Metallurgicall and Materials Transactions A (2001), 
32A, pp. 569-576 2 CO.

[15] Falvo, A.; Furgiuele, F.M.; Maletta, C.; Laser welding of a NiTi alloy: Mechanical and shape memory behaviour, Italy 2005.

[16] Falvo, A.; Furgiuele, F.M.; Maletta, C.; Functional behavior of a NiTi-welded joint: Two-way shape memory effect, Materials Science and Engineering A 481-482 (2008) pp. 647-650.

[17] Tuissi, A.; Besseghini, S.; Ranucci, T.; Squatrito F.; Pozzi, M.; Effect of a Nd-YAG laser welding on the functional properties of the Ni-49.6 at \% Ti, Materials Science and Engineering A273275 (1999) pp. 813-817.

[18] Gugel, H.; Schuermann, A.; Theisen, W.; Laser welding of NiTi wires, Materials Science and Engineering A 481-482 (2008) pp. 668-671.

[19] Pouquet J.; Miranda R. M.; Quintino L.; Williams S.; Dissimilar Laser Welding of Nitinol to Stainless Steel, International Journal of Advanced Materials Technology, 61, (2012), pp. 205212.

[20] Chatterjee, S.; Abinandanan T.A.; Chattopadhyay K.; Microstructure development during dissimilar welding: Case of laser welding of $\mathrm{Ti}$ with $\mathrm{Ni}$ involving intermetallic phase formation, J Mater Sci 41 (2006) pp. 643-652.

[21] Vieira L.; Laser welding of shape memory alloys, MSc thesis, Universidade Nova de Lisboa, (2010).

[22]Vieira M.T.;_Ramos A. S.; Cavaleiro A. J.; Miranda R. M.; Reactive nanolayers for microjoiningshape memory alloys, IIW Comission XVII, Denver (2012). 